\title{
Sickle cell-beta-thalassemia disease syndrome
}

INSERM

\section{Source}

INSERM. (1999). Orphanet: an online rare disease and orphan drug data base. Sickle cellbeta-thalassemia disease syndrome. ORPHA:251359

A rare, genetic hemoglobinopathy that affects red blood cells both in the production of abnormal hemoglobin, as well as the decreased synthesis of beta globin chains. Clinical manifestations depend on the amount of residual beta globin chains production, and are similar to sickle cell disease, including anemia, vascular occlusion and its complications, acute episodes of pain, acute chest syndrome, pulmonary hypertension, sepsis, ischemic brain injury, splenic sequestration crisis and splenomegaly. 